\title{
Simulation and field measurements of phytoplankton-bacteria-zooplankton interactions in the southern Benguela upwelling region
}

\author{
S. J. Painting ${ }^{1,2}$, C. L. Moloney ${ }^{2}$, M. I. Lucas ${ }^{2}$ \\ ${ }^{1}$ Benguela Ecology Programme, Sea Fisheries Research Institute, Private Bag X2, Roggebaai 8012, South Africa \\ ${ }^{2}$ Benguela Ecology Programme, Marine Biology Research Institute, Zoology Department, University of Cape Town, \\ Rondebosch 7700, South Africa
}

\begin{abstract}
A general size-based model is used here to predict the complex temporal successions observed in planktonic communities after an upwelling event in the southern Benguela, and to resolve a number of fundamental questions regarding the trophic dynamics of the pelagic food web. The model was not based on field data, and simulation results do not exactly mimic field and laboratory results. Nonetheless, the simulation model makes a major contribution towards our understanding of the dynamics of the planktonic food web after upwelling. The model predicts rapid growth of a phytoplankton community dominated by nanophytoplankton-sized cells and a later netphytoplankton bloom. After nitrate depletion the bloom is dominated by nanophytoplankton dependent upon regenerated nitrogen. Analysis of $\mathrm{C}$ and $\mathrm{N}$ flows showed that respiration and grazing were largely responsible for the decline of the phytoplankton bloom, accounting for 47 and $44 \%$ respectively of the total $\mathrm{C}$ fixed by phytoplankton over the 20 d period. Mesozooplankton grazed $62 \%$ of the declining bloom (Days 10 to 20 ), but only $18 \%$ of the total C fixed. This was due to the dominance of nanophytoplankton primary producers, which were unavailable to the larger mesozooplankton, but were consumed by microzooplankton. The microbial food web played an important role in $\mathrm{N}$ cycling and in the production of mesozooplankton throughout the simulation period. To determine the relative importance of the classical diatom-dominated food chain versus the microbial food web during one upwelling event, network analysis was used to assess $\mathrm{C}$ and $\mathrm{N}$ flows in the model foodweb. The total dependency coefficients showed that mesozooplankton depend mainly on netphytoplankton $(76 \%)$ for $C$ during the first $10 \mathrm{~d}$ of the phytoplankton bloom, but depend equally on netphytoplankton (70\%) and microzooplankton $(69 \%)$ for $\mathrm{N}$. During the last $5 \mathrm{~d}$ of the bloom, the biomass of both major prey items is low, and mesozooplankton depend equally ( 21 to $22 \%$ ) on netphytoplankton and microzooplankton for both $\mathrm{C}$ and $\mathrm{N}$. Food chains are longer and trophic efficiency decreases. The frequency of upwelling in the southern Benguela may thus be an important factor determining the relative dominance of short diatom-based food chains versus the microbial food web, and therefore the annual yield of pelagic fish.
\end{abstract}

\section{INTRODUCTION}

Since the relatively recent incorporation of microheterotrophs into the classical concept of the trophic dynamics of the pelagic ecosystem (Williams 1981, Azam et al. 1983), Ryther's (1969) hypothesis of high fish production in upwelling areas and the dominance of short, efficient diatom-based food chains has been a source of controversy. The southern Benguela, which supports the commercially important anchovy Engraulis capensis, appears to be amongst the least productive of the upwelling systems (Hutchings 1992). James (1987) has shown that copepods and euphausiids form the bulk of the diet of this species. Recent fluctuations in fisheries yield suggest that anchovy stocks may be sensitive to environmental changes which affect the planktonic food web and the availability of zooplankton in the pelagic environment (K. L. Cochrane \& L. Hutchings unpubl.).

The dynamics of phytoplankton growth in upwelling plumes in the southern Benguela are well documented (Barlow 1982, Brown \& Hutchings 1987 a, b). Primary 
production is high, but field studies have indicated that very little of the new production is consumed by mesozooplankton grazers (<10\%, Peterson et al. 1990) or through sedimentation ( $<15 \%$, Pitcher et al. 1989). It appears that a large proportion of the phytoplankton production may be channelled through microzooplankton and the microbial food web (Probyn 1992), rather than through the diatom-copepod food chain. Recent studies to determine the structure and functioning of the pelagic food web in the southern Benguela have focussed on the zooplankton and microheterotrophic components of the planktonic community (see Matthews 1991, Verheye et al. 1992, Painting et al. 1989, 1993). Densities and standing stocks are high, but temporal and spatial variability in these estimates suggests adaptive responses to phytoplankton dynamics and hydrographic processes (Verheye 1991, Brown et al. 1992, Verheye et al. 1992).

Temporal changes in the biomass of phytoplankton, bacteria, flagellate and zooplankton communities during the development of a discrete plume of upwelled water in the southern Benguela have been investigated during a number of drogue and laboratory studies (Barlow 1982, Brown \& Hutchings 1987a, b, Painting et al. 1989, 1993). As a result of these studies a number of hypotheses of the processes governing temporal changes in biomass relationships and sizestructure of the plankton community were developed. Such hypotheses are difficult to test in the field, as it is almost impossible to obtain good time series data. Firstly, there are numerous problems associated with following a drogue. Furthermore, it is extremely difficult to measure all biomasses and flows in a plankton community simultaneously. Under these circumstances simulation models are extremely useful to help fill in any gaps in the data, and for analysing fluxes within the different components of the foodweb.

This study uses a theoretical size-based model (Moloney \& Field 1991a) to simulate complex temporal successions in the planktonic communities in the southern Benguela upwelling region, and to explore the relative importance of nutrient limitation, grazing, senescence and sinking in causing the decline of a phytoplankton bloom after upwelling. The model parameters are not based on any local field or laboratory data, but starting values are tuned to produce output consistent with observations of the sequence of changes occurring after upwelling. Model flows are used in network analysis to assess the potential amount of phytoplankton available for copepod production, and the dependence of copepods in the model on a predominantly microzooplankton diet. The model is also used to investigate the role of bacterioplankton in the planktonic food web of the southern Benguela, with special reference to their role in enhancing primary production.

\section{DESCRIPTION OF THE MODEL}

The model, based on the trophic continuum concept of Cousins (1985) and general ecological principles, has been used to simulate hypothetical food webs in 3 hydrographically different regions of the Benguela (Moloney \& Field 1991b, Moloney et al. 1991). Here, the model has been modified to simulate the dynamics of the pelagic food web in a plume of upwelled water after a single upwelling event.

Planktonic communities were divided into autotroph and heterotroph groups, which were then subdivided into discrete size-classes. Autotrophs $(<200 \mu \mathrm{m})$ were assigned to 3 size-classes, whereas heterotrophs $(<2000 \mu \mathrm{m})$ were divided into 4 size-classes. Three abiotic compartments were included in the model: dissolved organic nitrogen (DON), dissolved organic carbon (DOC), and particulate organic carbon (POC) and nitrogen (PON). Cell volumes were calculated using the formula for a sphere. For autotrophs and bacteria, cell volumes were converted to carbon using Strathmann's (1967) equations. A factor of $0.07 \mathrm{pg} \mathrm{C}$ $\mu \mathrm{m}^{-3}$ was used for other heterotrophs (Moloney \& Field 1991a).

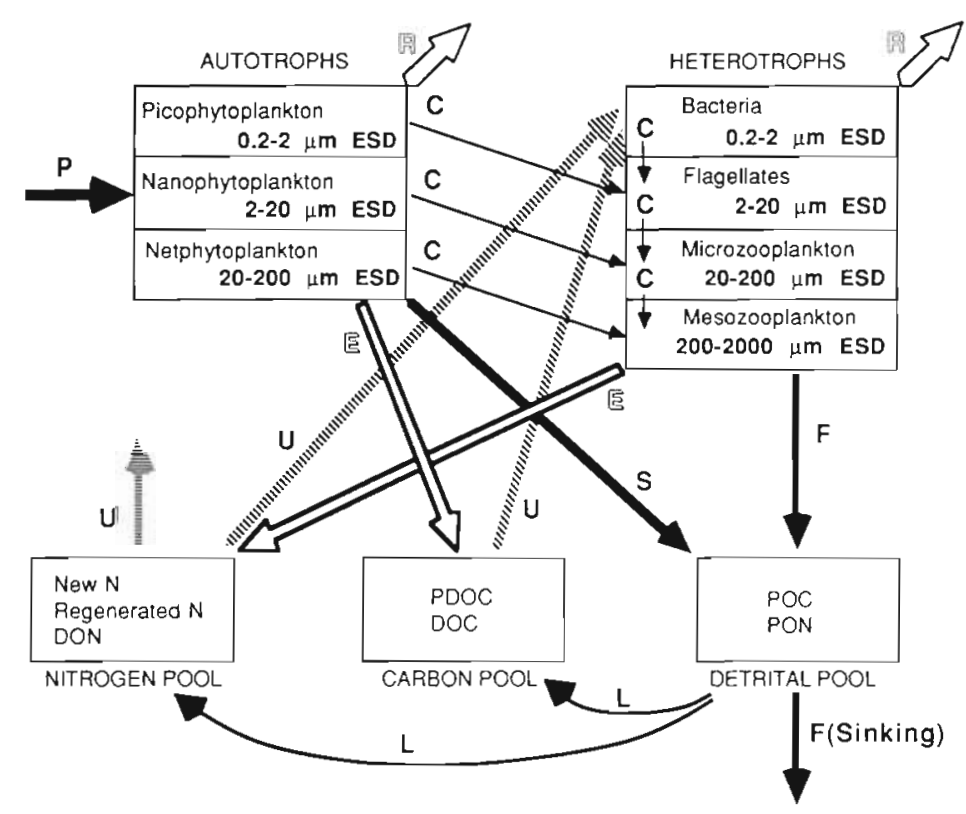

Fig. 1. Major carbon and nitrogen flows in the size-based simulation model (Moloney \& Field 1991a). P: photosynthesis; U: uptake; R: respiration; E: excretion/secretion; $S$ : senescence; $C$ : consumption (grazing/predation); L: lysis of particulate material; ESD: equivalent spherical diameter 
The size-ranges of organisms in the autotroph and heterotroph continua and the conceptual model of the major carbon (C) and nitrogen ( $N$ ) flows in the dynamic simulation model used in this study are shown on Fig. 1. Categorisation of autotrophs as pico-, nano- and netphytoplankton follows the conventional nomenclature (see Sieburth 1984). It is important to emphasise that both diatoms and flagellates are present in each of the size-classes. For convenience, heterotroph compartments are named according to the familiar groups of animals in each size-class (see also Azam et al. 1983) although categories are not exclusive and the representative taxon is not necessarily dominant.

Autotrophs fix $\mathrm{C}$ during photosynthesis and take up dissolved $\mathrm{N}$. Losses of $\mathrm{C}$ are due to excretion of photosynthetically produced dissolved organic carbon (PDOC), respiration, grazing and senescence. Bacteria obtain $C$ and $N$ from the dissolved pools, whereas larger heterotrophs ingest particulate material (autotrophs and heterotrophs in the size-class smaller than their own). Loss of $\mathrm{C}$ from bacteria is due to respiration and predation. Losses of $\mathrm{C}$ from other heterotrophs are due to egestion, respiration and predation.

New' nitrogen (nitrate) was the only external input to the model (Fig. 1); regenerated nitrogen resulted from cycling of reduced nitrogen (urea, ammonia) by heterotrophs (excretion). The dissolved and particulate pools received inputs from autotrophs (PDOC, senescence, lysis) and heterotrophs (egestion, excretion)

In the model, rates of nutrient uptake, ingestion and respiration are calculated using the general allometric equations estimated from data covering a wide range of organism sizes (Moloney \& Field 1989). Other model parameters are estimated from regression models derived from published data (Moloney \& Field 1991a). These include half-saturation constants $\left(K_{\mathrm{s}}\right)$ for nitrogen uptake by phytoplankton and bacteria, and $K_{\mathrm{s}}$ for ingestion of prey organisms. None of the field data were used to estimate these parameters in the model.

The model is 'driven' by nitrogen concentrations in the dissolved pool, which result in the growth of phytoplankton. Execution of the model allows temporal changes in standing stocks and the size structure of the planktonic community to be described. The model calculates changes in $\mathrm{C}$ and $\mathrm{N}$ flows through the community with time. These can be used to analyse the dynamics of the model system. Numerous options are available for executing simulations, making it possible to simulate the dynamics of planktonic communities under a variety of assumed conditions.

In this study, the model simulation was executed over 20 days, using a time increment of $0.05 \mathrm{~d}$ in a second-order Runge Kutta method (see Moloney \& Fjeld 1991a). Values of parameters used are shown in Table 1. Some rate parameters were adjusted to allow for the assumed ambient water temperature $\left(13^{\circ} \mathrm{C}\right)$ using a $Q_{10}$ value of 2 (Parsons et al. 1984). The average size of picophytoplankton (1 $\mu \mathrm{m}$ equivalent spherical diameter, ESD; Stockner \& Antia 1986) was made larger than that of bacterioplankton $(0.6 \mu \mathrm{m}$ ESD), making picophytoplankton growth and respiration rates somewhat slower than those of bacterioplankton, although both groups fall within the same size-class (Table 1).

Starting values are listed in Table 1. Standing stocks of autotrophs in newly upwelled water were adopted from Moloney \& Field (1991a). PDOC excretion rates were assumed to be constant, at $15 \%$ of the total $\mathrm{C}$ fixed during photosynthesis (see Lancelot 1984, Lucas 1986). C: $N$ ratios of 6.0 and 4.5 to 5.0 were adopted for autotrophs and heterotrophs respectively (Newell \& Linley 1984, Moloney et al. 1991). More than 50 simulations were executed to estimate realistic refuge sizes, senescence and lysis rates of phytoplankton, and initial starting values of heterotrophs (Table 1).

To keep the simulations as simple as possible, physical mixing of the water column, sinking of phytoplankton cells, and growth of organisms into larger sizeclasses were not included. Organisms capable of adopting nutritional modes other than either photosynthesis or heterotrophy were excluded. Major assumptions are listed below. They are based on a range of field and laboratory measurements in the Benguela and other systems, or reflect recent hypotheses on the structure and functioning of the pelagic food web.

1. Ambient water temperature is $13^{\circ} \mathrm{C}$, and the $Q_{10}$ for all planktonic organisms is 2 .

2. Light conditions in the euphotic zone are optimal.

3. Nitrogen limits phytoplankton growth.

4. Phytoplankton growth in upwelled water is dependent upon a single initial pulse of nitrate (ca $25 \mathrm{mg}$ at. $\mathrm{N} \mathrm{m}^{-3}$ ) into the euphotic zone. After depletion of 'new' nitrate, phytoplankton growth is dependent upon recycled nutrients.

5. Excretion of PDOC by phytoplankton is constant at $15 \%$ of gross production.

6. Bacteria are able to utilise dissolved inorganic nitrogen. They are not nitrogen limited when inorganic nitrogen concentrations are high.

7. Phytoplankton senescence occurs at a constant rate of $10 \%$ of the gross production per day, contributing to the detrital carbon and nitrogen pool.

8. Bacteria break down (lyse) senescent phytoplankton cells at a rate of $10 \%$ of the total senescence rate per day. 
Table 1 Values of parameters and starting values used to simulate carbon and nitrogen flows through the planktonic community. Ambient temperature was assumed to be $13{ }^{\circ} \mathrm{C}$. All abiotic pools were initialised at $0 \mathrm{mg}$-at. $\mathrm{m}^{-3}$, except new nitrogen $\left(25 \mathrm{mg}\right.$-at. $\left.\mathrm{N} \cdot \mathrm{m}^{-3}\right)$. ESD = equivalent spherical diameter

\begin{tabular}{|c|c|c|c|c|}
\hline Parameters & $0.2-2 \mu \mathrm{m}$ & $2-20 \mu \mathrm{m}$ & $20-200 \mu \mathrm{m}$ & $200-2000 \mu \mathrm{m}$ \\
\hline \multicolumn{5}{|l|}{ Autotrophs } \\
\hline Average ESD $(\mu \mathrm{m})$ : & 1.00 & 6.30 & 63.00 & - \\
\hline Maximum growth rate ${ }^{d}\left(\mathrm{~d}^{-1}\right)$ & 3.10 & 1.10 & 0.30 & - \\
\hline Respiration rate ${ }^{d}\left(d^{-1}\right)$ & 1.50 & 0.50 & 0.10 & - \\
\hline $\begin{array}{l}\text { Half saturation constant } \\
\text { for } \mathrm{N} \text { uptake }{ }^{b}\left(\mathrm{mg} \mathrm{N}^{-3}\right)\end{array}$ & 0.95 & 5.70 & 41.5 & - \\
\hline PDOC production rate ${ }^{c}\left(\mathrm{~d}^{-1}\right)$ & 0.15 & 0.15 & 0.15 & - \\
\hline Initial standing stocks ${ }^{\circ}\left(\mathrm{mg} \mathrm{C} \mathrm{m}^{-3}\right)$ & 0.50 & 5.00 & 50.00 & - \\
\hline Refuge size $\left(\mathrm{mg} \mathrm{C} \mathrm{m} \mathrm{m}^{-3}\right)$ & 1.00 & 1.00 & 1.00 & - \\
\hline Senescence rate ${ }^{\mathrm{d}}\left(\mathrm{d}^{-1}\right)$ & 0.31 & 0.11 & 0.03 & - \\
\hline Lysis rate $\left(\mathrm{d}^{-1}\right)$ & 0.10 & 0.10 & 0.10 & - \\
\hline C:N Ratioc & 6.00 & 6.00 & 6.00 & - \\
\hline Average $\mathrm{C}$ mass $^{a}\left(\mathrm{pg} \mathrm{C}\right.$ cell $\left.{ }^{-1}\right)$ & 0.14 & 16.00 & 2780.00 & - \\
\hline \multicolumn{5}{|l|}{ Heterotrophs } \\
\hline Average $\operatorname{ESD}(\mu \mathrm{m})$ : & 0.63 & 6.30 & 6.3 .00 & 630.00 \\
\hline Maximum uptake rate ${ }^{d}\left(d^{1}\right)$ & 4.10 & - & - & - \\
\hline Maximum ingestion rate " $\left(\mathrm{d}^{-1}\right)$ & - & 22.20 & 4.00 & 0.70 \\
\hline Respiration rate ${ }^{d}\left(\mathrm{~d}^{-1}\right)$ & 1.90 & 4.90 & 0.88 & 0.16 \\
\hline $\begin{array}{l}\text { Half saturation constant } \\
\left.\text { for } \mathrm{N} \text { uptake } \mathrm{mg} \mathrm{m}^{-3}\right)\end{array}$ & 0.80 & - & - & - \\
\hline $\begin{array}{l}\text { Half saturation constant } \\
\quad \text { for predation }{ }^{\mathrm{b}}\left(\mathrm{mg} \mathrm{C} \mathrm{m}^{-3}\right)\end{array}$ & 37.10 & 64.50 & 112.10 & 194.90 \\
\hline Initial standing stocks ${ }^{\mathrm{d}}\left(\mathrm{mg} \mathrm{C} \mathrm{m}^{-3}\right)$ & 0.50 & 0.50 & 5.00 & 5.00 \\
\hline Refuge sized $\left(\mathrm{mg} \mathrm{C} \mathrm{m} \mathrm{m}^{-3}\right)$ & 1.00 & 1.00 & 1.00 & 1.00 \\
\hline C Nratio ${ }^{c}$ & 4.00 & 4.50 & 4.50 & 4.50 \\
\hline Assimilation efficiency ${ }^{c}\left(d^{-1}\right\}$ & 1.00 & 0.85 & 0.85 & 0.85 \\
\hline Average $\mathrm{C}$ mass $^{a}\left(\mathrm{pg} C\right.$ cell $\left.^{-1}\right)$ & 0.09 & 9.30 & 9300.00 & $9.3 \times 10^{6}$ \\
\hline \multicolumn{5}{|c|}{ Values calculated using allometric equations (Moloney \& Field 1989) } \\
\hline \multicolumn{5}{|c|}{${ }^{b}$ Estimated from size-based regression models (Moloney \& Field 1991a) } \\
\hline \multicolumn{5}{|c|}{ Adopted from Moloney \& Field (1991a) } \\
\hline${ }^{\mathrm{d}}$ Estimates resulting in realistic mod & & & & \\
\hline
\end{tabular}

9. Bacteria are nitrogen- and carbon-limited at the start of the simulation. The dissolved carbon pool was therefore initialised at $0 \mathrm{mg}$-at. $\mathrm{C} \mathrm{m}^{-3}$.

10. Faecal material sinks rapidly below the euphotic zone, and is thus instantaneously removed from the model system.

A standard output was produced, based on the above assumptions and parameters, and compared with laboratory and field measurements (see below). One of our objectives was to assess the importance of different interactions and processes. To do this, simulations were manipulated by altering selected parameters and/or assumptions. The techniques of Network Analysis were used to analyse integrated flows and biomasses during selected periods of the standard simulation. The program NETWRK3 (Ulanowicz 1986, Wulff et al. 1989) was used to analyse the trophic structures of the carbon and nitrogen flow networks in order to assess the trophic importance of the heterotrophic component of the microbial food web.

\section{RESULTS AND DISCUSSION}

\section{Autotrophs}

Pulses of high phytoplankton biomass developed in the model system (Fig. 2a). A small initial peak of short duration was observed on Day 1, and was dominated by picophytoplankton. Phytoplankton biomass reached a peak of $960 \mathrm{mg} \mathrm{C} \mathrm{m}{ }^{-3}$ on Day 4. This bloom, dominated by nanophytoplankton, declined rapidly on Day 5 and was followed by a series of blooms of picophytoplankton. The first of these showed a high biomass ( $850 \mathrm{mg} \mathrm{C} \mathrm{m}^{-3}$ ), and lasted for ca $2 \mathrm{~d}$. Thereafter. the magnitude and duration of picophytoplankton blooms became progressively smaller. The biomass of netphytoplankton increased very slowly. This sizeclass, preyed upon by the slow-growing mesozooplankton, did not exhibit rapid cycling, and increased gradually from an initial standing stock of $50 \mathrm{mg} \mathrm{C} \mathrm{m}{ }^{-3}$ to ca $420 \mathrm{mg} \mathrm{C} \mathrm{m}^{-3}$ on Day 11. Netphytoplankton dom- 

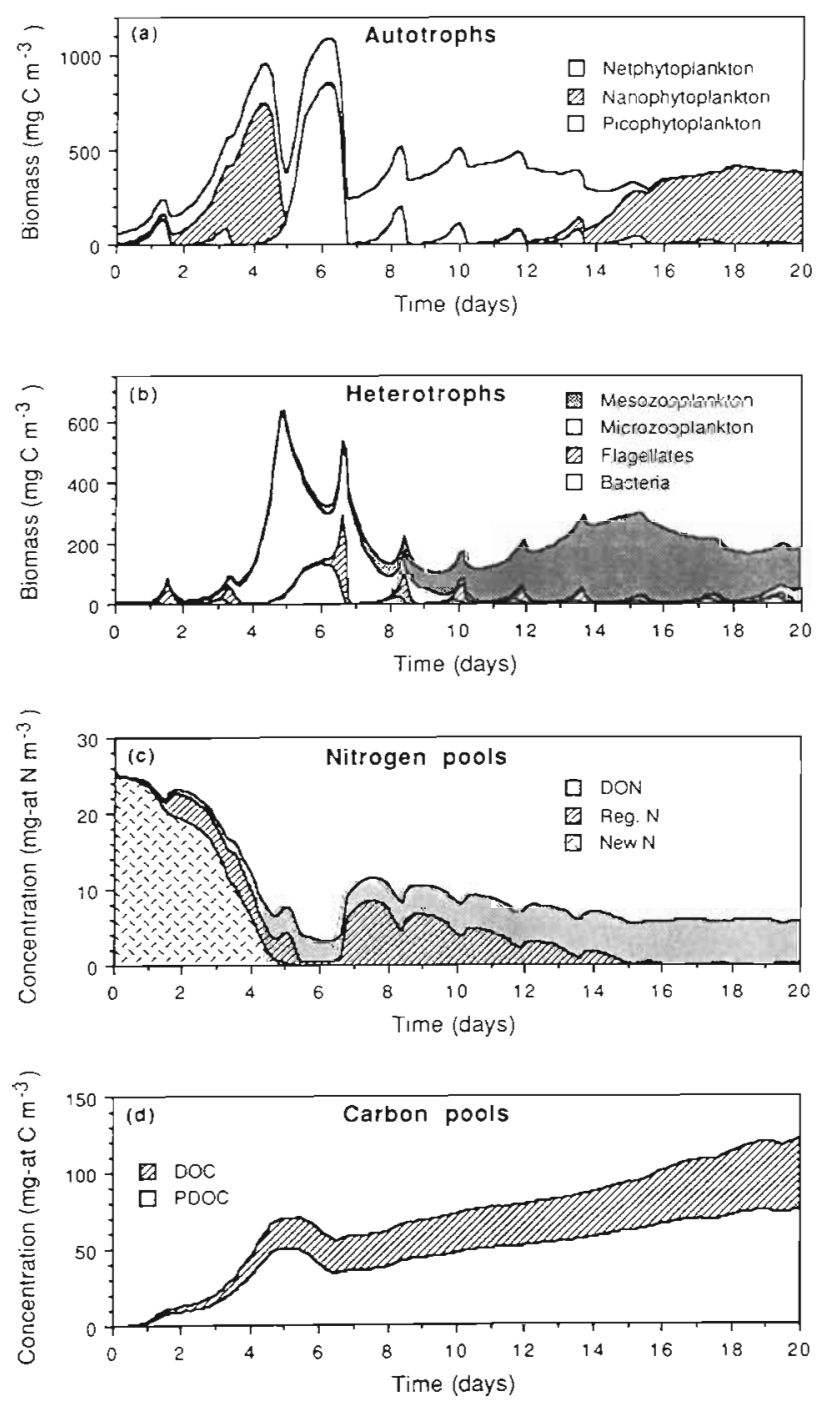

Fig. 2. Model output showing changes in biomass of (a) autotrophs and (b) heterotrophs in the planktonic community, and changes in concentrations of (c) nitrogen and (d) carbon pools after upwelling. Total biomass values and concentrations are shown. Shading represents the relative contribution by each size-class or nutrient compartment. DON: dissolved organic nitrogen; DOC: dissolved organic carbon; PDOC: photosynthetically produced DOC; Reg. N: regenerated N

inated the autotroph biomass from Days 7 to 14 . After Day 12 a second bloom of nanophytoplankton developed. This bloom was considerably smaller than the first nanophytoplankton bloom and persisted throughout the remainder of the simulation (20 d).

\section{Heterotrophs}

Pulses of bacterial biomass were observed in the simulation (Fig. 2b). Bacterial biomass changes showed similar trends to the picophytoplankton, but with smaller magnitudes. A maximum bacterial biomass of $135 \mathrm{mg} \mathrm{C} \mathrm{m}{ }^{-3}$ developed on Day 6 . Flagellates and microzooplankton fluctuated in response to phytoplankton and heterotroph blooms in their optimal food size-class.

Microzooplankton fluctuations after Day 5, when their nanophytoplankton food source was absent, were in response to flagellate blooms. Mesozooplankton biomass was low initially, due to a low starting value. The slow growth rates of this size-class resulted in a very gradual increase in their biomass, up to a maximum of $280 \mathrm{mg} \mathrm{C} \mathrm{m}^{-3}$ on Day 15. Rapid fluctuations in mesozooplankton biomass were not observed in the model.

\section{Nitrogen and carbon pools}

Concentrations of nitrate were initially high (Table 1 , Fig. 2c) and decreased during the picophytoplankton and bacterial blooms prior to Day 2. This 'new' nitrogen pool continued to decrease as a result of uptake by nanophytoplankton, and was depleted by Day 5. The supply of regenerated nitrogen was pulsed, and cycled with the blooms of bacteria and other heterotrophs. The pool of DON was zero initially, and increased continually due to phytoplankton senescence and lysis.

The PDOC pool (Fig. 2d) was zero initially and increased rapidly during the initial pico-and nanophytoplankton blooms to a concentration of $50 \mathrm{mg}$-at. $\mathrm{C} \mathrm{m}^{-3}$ on Day 5. The PDOC pool was reduced during the bacterial bloom on Day 6, and increased during the remainder of the simulation due to further phytoplankton blooms. The PDOC and DOC pools are potentially available for bacterial utilisation, but are not used because bacteria become nitrogen-limited toward the end of the simulation and carbon accumulates.

\section{Comparison of simulation output with field data}

Temporal development of phytoplankton in the simulation output presented here appears to conform well with field observations on bloom development after upwelling in the southern Benguela (Fig. 3). Drogue studies by Barlow (1982) and Brown \& Hutchings $(1987 \mathrm{a}, \mathrm{b})$ have shown that the combination of light, high nutrients and sun-warming after upwelling results in rapid development of phytoplankton blooms, dominated by chain-forming diatoms. These blooms typically take about $3 \mathrm{~d}$ to develop, reaching maximum standing stocks of up to $21 \mathrm{mg}$ chl a $\mathrm{m}^{-3}(1300 \mathrm{mg}$ $\mathrm{C} \mathrm{m}^{-3}$ ) and decline 6 to 8 d later due to thermal stratifi- 


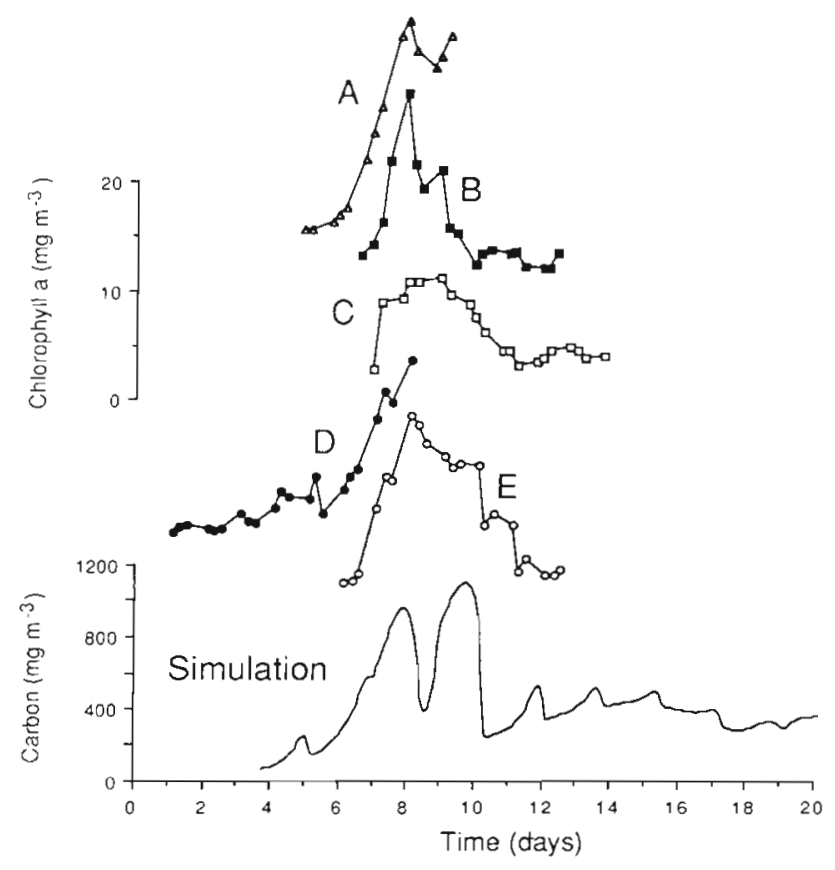

Fig. 3. Comparison of simulation output (mg $\mathrm{C} \mathrm{m}^{-3}$ ) and field measurements of phytoplankton biomass $\left(\mathrm{mg} \mathrm{chl} \mathrm{m}^{-3}\right.$ ) obtained during 5 drogue studies ( $A$ to $E$ ) in the southern Benguela (after Brown \& Hutchings 1987a). Time axes have been shifted so that biomass peaks coincide

cation and nitrate limitation. The cells either sink out of the water column or are grazed by herbivores. Any further production is sustained by regenerated nitrogen (Probyn 1985, 1987).

Temporal successions and biomass values for phytoplankton and zooplankton predicted by the size-based model (Fig. 4a) are similar to measurements obtained during the second of the 2 drogues followed by Painting et al. (1993) (Fig. 4b). Detailed comparison of field data with simulation output is, however, complicated by the different lengths of time involved in each study, and by evidence suggesting that the drogue did not stay with the same water mass. Temporal biomass changes observed in the field appeared to be acceler. ated due to movement of the drogue out of maturing upwelled water (MUW) into older MUW/mixed water (Painting et al. 1993). The 'break-point' in each data series is indicated by an arrow (Fig. 4b, c). The data were decoupled at this point and shifted independently along the time axis for comparisons with the simulation. Estimates of the relative proportions of nano- and netphytoplankton biomass (Fig. 4c) were obtained from cell counts in surface waters. Cells were grouped into the nano- and netphytoplankton sizeclasses on the basis of equivalent spherical diameters, and counts $\left(\mathrm{ml}^{-1}\right)$ were converted to $\mathrm{C}$ biomass using Strathmann's (1967) equations for flagellates and dia- toms. Each of the 2 size-classes contributed approximately $50 \%$ of the total biomass.

Changes in the total biomass of phytoplankton, bacteria and zooplankton in MUW are shown superimposed on simulation results in Fig. 5. On the basis of nitrate concentrations ( 2 to $5 \mathrm{mg}$-at. $\mathrm{N} \mathrm{m}^{-3}$ ) and increasing phytoplankton biomass (Painting et al.1993). the field data in MUW were shifted to coincide with Days 2 to 4 in the simulation study. The measured phytoplankton biomass was, however, low for MUW in which 'new' nitrogen was still present at low concentrations, and the phytoplankton community was not dominated by the nanophytoplankton size-class (Fig. 4c) evident in the model. In situ nanophytoplankton biomass may have been underestimated due to the difficulties of preserving and counting cells less than $15 \mu \mathrm{m}$ (Bloem et al. 1986). Furthermore, the small chain-forming diatom cells, which dominate the initial netphytoplankton bloom, may fall into the nanoplankton category as a result of the small size of individual cells. In terms of the cell metabolic rates this classification is likely to be valid, but by forming chains these cells are effectively netplankton and are therefore likely to avoid predation by microzooplankton. Increased availability of the effective netphytoplankton biomass, which is available to mesozooplankton grazers, may have a significant impact on the structure and functioning of the pelagic food web (see Painting et al. 1992).

The biomass data in older MUW/mixed water coincided with the simulation data from Days 14 to 16 (not shown here). Although fluctuations were observed in the field data, total biomass values were comparable. Cell counts (Fig. 4c) also indicated the simulated succession in the dominant phytoplankton, from netphytoplankton to nanoplankton.

For bacteria, the maximum biomass value in the model output (135 $\mathrm{mg} \mathrm{C} \mathrm{m}^{-3}$; Fig. 2b) was similar to the maximum biomass value measured in the field (180 mg $\mathrm{C} \mathrm{m}^{-3}$; Painting et al.1993). Agreement between simulation and field results was good for older MUW/mixed water, but poor in MUW (Fig. 5b) where the measured biomass was ca 5 times higher than the simulated biomass. This may be due to complicating factors such as the cell physiologies and substrate uptake activity of bacteria which operate in the field but are not included in the model, and which could delay bacterial growth and influence initial predator-prey interactions.

The temporal development of the simulated and field zooplankton communities (Fig 4a, b) showed similar trends. Measured mesozooplankton biomass was slightly higher than model mesozooplankton on Day 4 (Fig. 5), possibly due to a high biomass in the original seeding population. Increased grazing pressure by a 

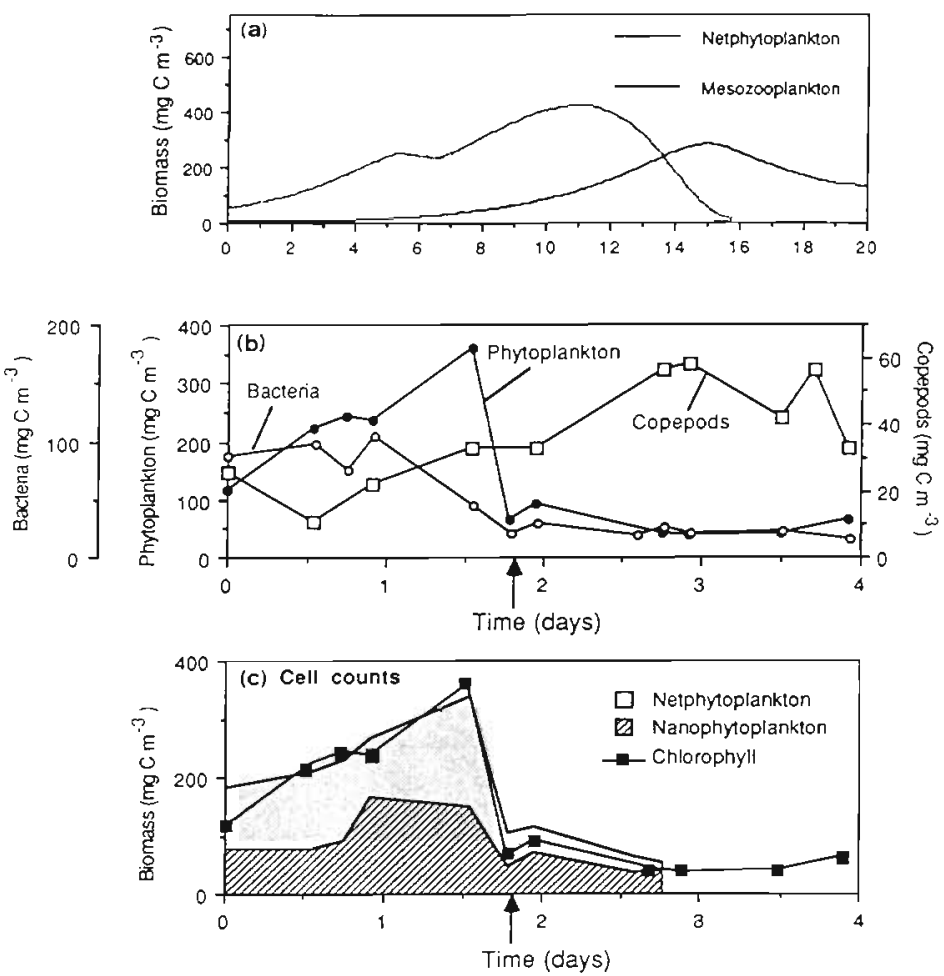

Fig. 4. (a) Temporal changes in the biomass of copepods and their netphytoplankton prey during the simulation. (b) Changes in the measured biomass of phytoplankton, bacteria and copepods during Drogue 2 (Painting et al. 1993). Phytoplankton biomass was calculated using a carbon:chlorophyll ratio of 60 . (c) Nano- and netphytoplankton biomass calculated from cell counts and pg C cell-1 (Strathmann 1967). Total chlorophyll biomass is also shown. Arrows indicate when the drogue moved out of maturing upwelled water into older water

relatively large mesozooplankton population on the effective netphytoplankton size-class may account for the low field phytoplankton biomass observed on Day 4. During the declining phase of the bloom the maximum biomass of model mesozooplankton $(280 \mathrm{mg} \mathrm{C}$ $\mathrm{m}^{-3}$, Day 15) was 5 times larger than that of the field community.

It is unrealistic to expect quantitative data to match the simulation results precisely, particularly towards the end of the simulation. In the field it is unlikely that the water mass being studied is not influenced by factors such as turbulence, the input of diffused nutrients, changes in the optical spectrum, and behaviour of migratory animals, particularly mesozooplankton and fish, which are free to move into and out of a particular water mass. In spite of this, and the de-coupling of the temporal sequence in the field data, the model used here appears to be a realistic simulation of the temporal changes in the biomass relationships and size-structure of the planktonic food web in an upwelling plume in the southern Benguela.

\section{Comparison of microcosm and model simulation}

The model was modified to simulate results obtained in a microcosm study (Painting et al. 1989), by excluding micro- and mesozooplankton. Model output is shown for both autotrophs (Fig. 6a) and heterotrophs (Fig. 6b). A small picophytoplankton bloom developed on Day 1, but decreased rapidly. This was followed by a phytoplankton peak on Day 4 (ca $1800 \mathrm{mg} \mathrm{C} \mathrm{m}^{-3}$ ), which was dominated by nanophytoplankton (1600 $\mathrm{mg} \mathrm{C} \mathrm{m}^{-3}$ ). Phytoplankton biomass declined gradually after Day 4 due to nitrate depletion, and the absence of herbivores.

Bacterial biomass showed a small peak (ca 5 $\mathrm{mg} \mathrm{C} \mathrm{m}^{-3}$ ) on Day 1 , which was followed by a peak in flagellate biomass (ca $80 \mathrm{mg} \mathrm{C} \mathrm{m}^{-3}$ ). The bacterial biomass decreased rapidly to the threshold value (1 $\mathrm{mg} \mathrm{C} \mathrm{m}^{-3}$ ) before Day 2 , and was followed by a decrease in flagellate biomass. The model showed 10 further predator-prey oscillations up to Day 20, when the simulation was terminated. In the absence of picophytoplankton blooms after Day 3, pulses in flagellate biomass followed changes in bacterial biomass. Maximum bacterial biomass in the simulation was ca $35 \mathrm{mg} \mathrm{C} \mathrm{m} \mathrm{Cm}^{-3}$.

Microcosm autotroph results (Fig. 7a) showed approximate agreement with the simulation output. Changes in relative fluorescence and concentrations of POC did not show any evidence of the initial picophytoplankton bloom on Day 1 (Fig. 6a), possibly due to inactivity of this group of organisms in recently upwelled water. The nanophytoplankton bloom on Day 4 was reflected by both the fluorescence and POC (1330 $\left.\mathrm{mg} \mathrm{C} \mathrm{m}^{-3}\right)$ measurements. The decline in fluorescence from Days 4 to 13 (Fig. 7a) suggested senescence of the phytoplankton bloom due to depletion of nitrates in the system (Painting et al. 1989). The decline in POC concentrations during this time period suggested utilisation of senescent phytoplankton cells by bacteria. After Day 12 POC concentrations fluctuated between 300 and $700 \mathrm{mg} \mathrm{C} \mathrm{m}^{-3}$, reflecting accumulation of the more refractory detrital phytoplankton in the absence of sinking and grazing by micro- and mesozooplankton.

A more realistic simulation output was achieved by increasing phytoplankton senescence rate 5-fold at Day 4, when new $N$ was depleted (Fig. 8a). Studies by Barlow (1982) and Brown \& Hutchings (1987a) have shown that phytoplankton senesce rapidly after the supply of 'new' nitrogen is diminished.

For heterotrophs, agreement between microcosm 

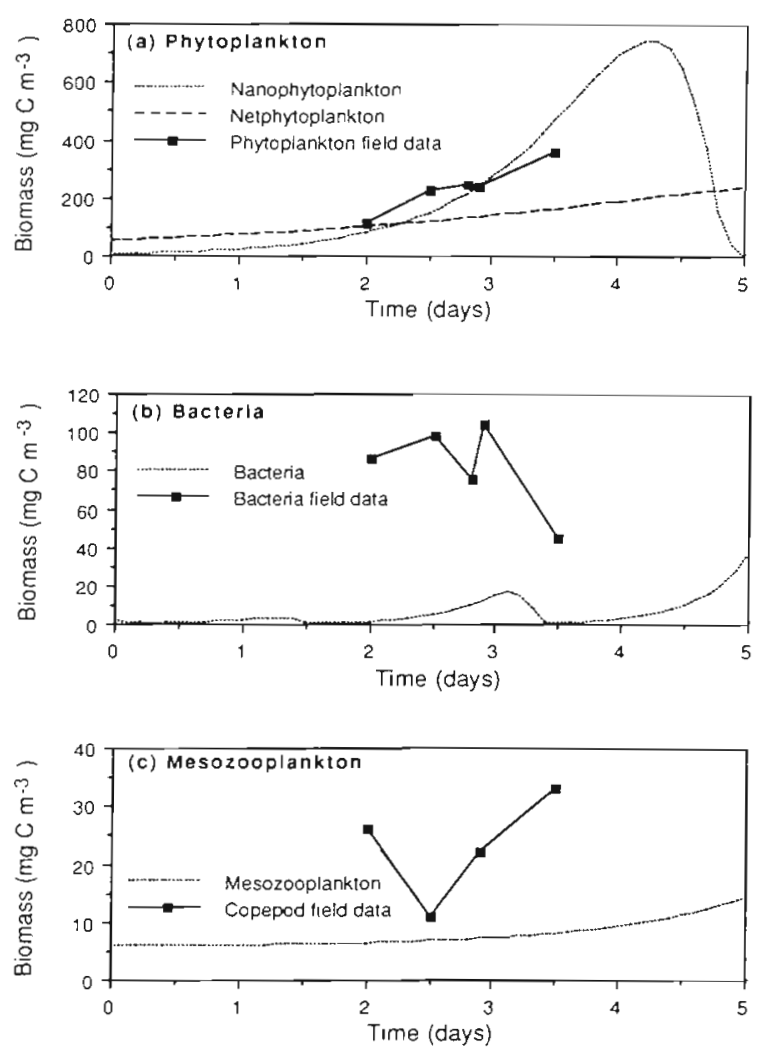

Fig. 5. Comparison of simulation output and field measurements of biomass in maturing upwelled water. (a) Phytoplankton. (b) Bacteria. (c) Mesozooplankton (copepods)

(Fig. 7b) and model simulations was poor (Figs. $6 \mathrm{~b} \&$ $8 \mathrm{~b}$ ), but the observed differences may be ascribed to growth parameters not catered for in the model. For example, the initial pulse of bacteria in the model may not occur due to suppressed metabolic rates of bacteria in newly upwelled water. Furthermore, bacteria in the model find refuge from predation only in their total biomass. Factors such as bacterial growth to a larger cell size or the presence of micro-environments, which offer some predation refuges to bacteria, are not included. Microcosm results showed that the bacterial community which developed on the more refractory particulate substrates after Day 10 was dominated by large rods. These bacteria did not appear to be grazed by flagellates, perhaps escaping predation due to their large cell size, or by association with particulate material (Painting et al. 1989). The degree to which this factor. could result in observed biomass changes was investigated using the model, by introducing a second bacterial size-class at Day 9. This size-class was assumed to comprise cells with a mean size of $1 \mu \mathrm{m}$ ESD (ca $0.65 \mu \mathrm{m}^{3}$; Lucas et al. 1987). It was assumed that their large size allowed these bacteria a refuge from predation. These manipulations enabled rapid growth
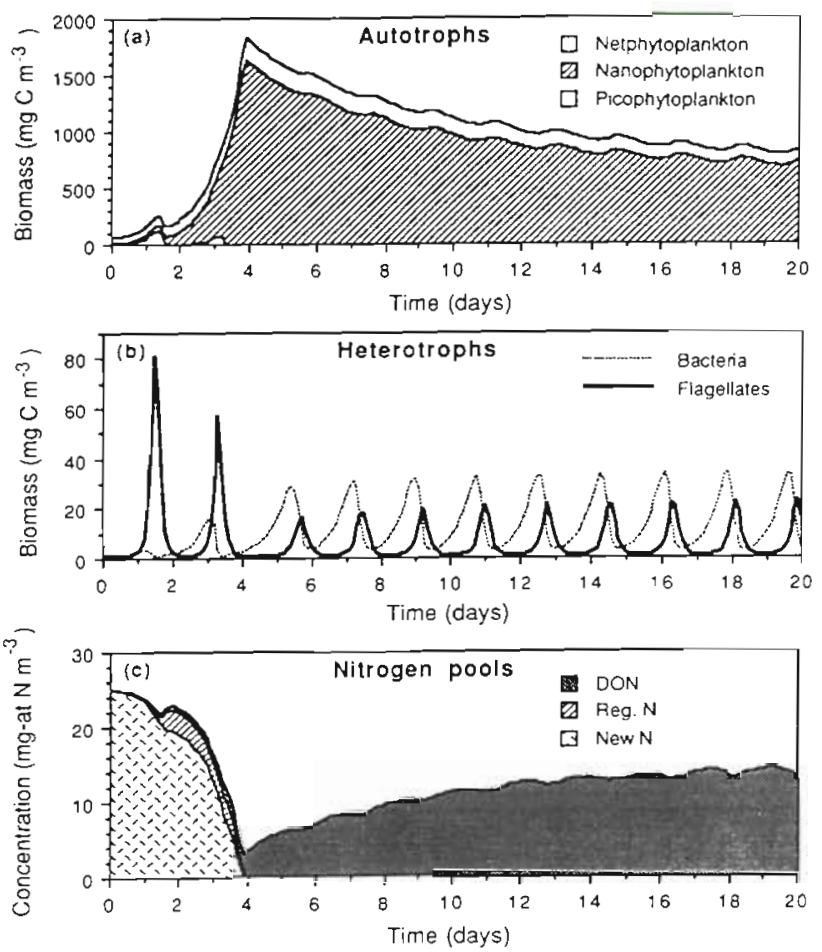

Fig. 6. Model results obtained from simulating the microcosm experiment (Painting et al. 1989). (a) Autotrophs. (b) Heterotrophs. (c) Nitrogen pools

of a bacterial community during the declining phase of the phytoplankton bloom (Fig. 9b), as observed in the microcosm.

\section{Different options for simulation of the planktonic food web}

A number of hypothetical options were experimented with in the model simulation of the planktonic food web. In the first, bacteria were assumed to utilise only dissolved sources of $\mathrm{C}$ and $\mathrm{N}$ (lysis of senescent phytoplankton cells was set to zero). Model output (Fig. 10) showed that autotrophs were initially unaffected. Up to Day 7 results were similar to those in Fig. 2a. Thereafter, autotroph biomass was reduced by half. Pulses of regenerated nitrogen were reduced (Fig. 10c; cf. Fig 2c), and the secondary nanophytoplankton bloom was much smaller. Similarly, heterotrophs were initially unaffected (Figs. 2b \& 10b), but after Day 5 total heterotroph biomass was reduced. These results show that if bacteria are assumed to utilise only PDOC and inorganic nitrogen, the microbial loop is less active in regenerating nitrogen and phytoplankton production declines more rapidly. Bacteria may supplement their $\mathrm{C}$ and $\mathrm{N}$ requirements by digesting detrital material such as senescent phyto- 

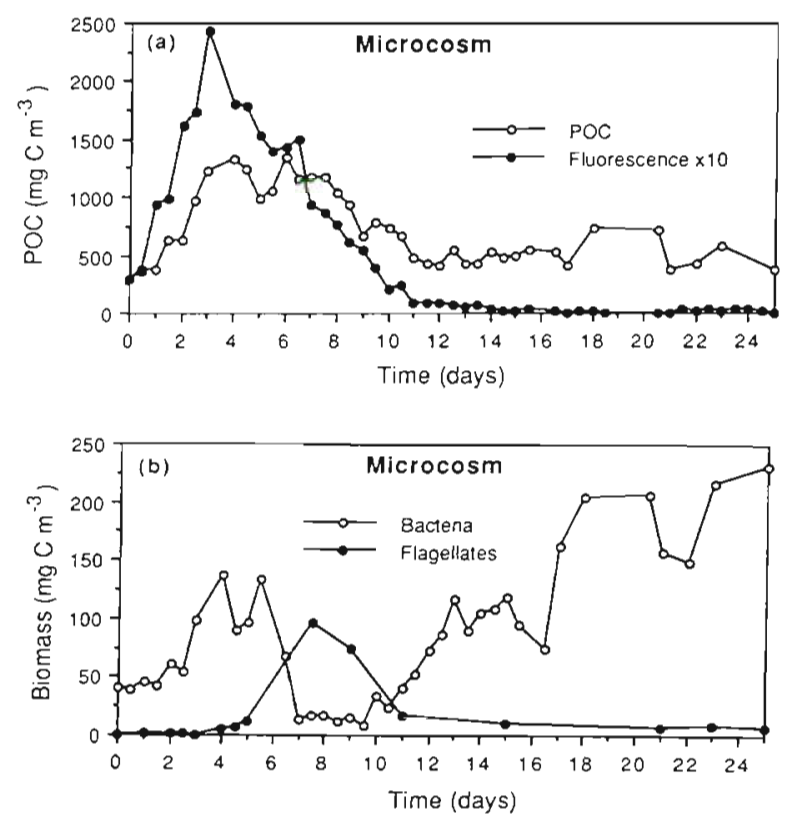

Fig. 7. Biomass changes during phytoplankton growth and decay in a microcosm study (Painting et al. 1989). (a) Relative fluorescence and particulate organic carbon (POC) concentrations. (b) Bacteria and flagellates
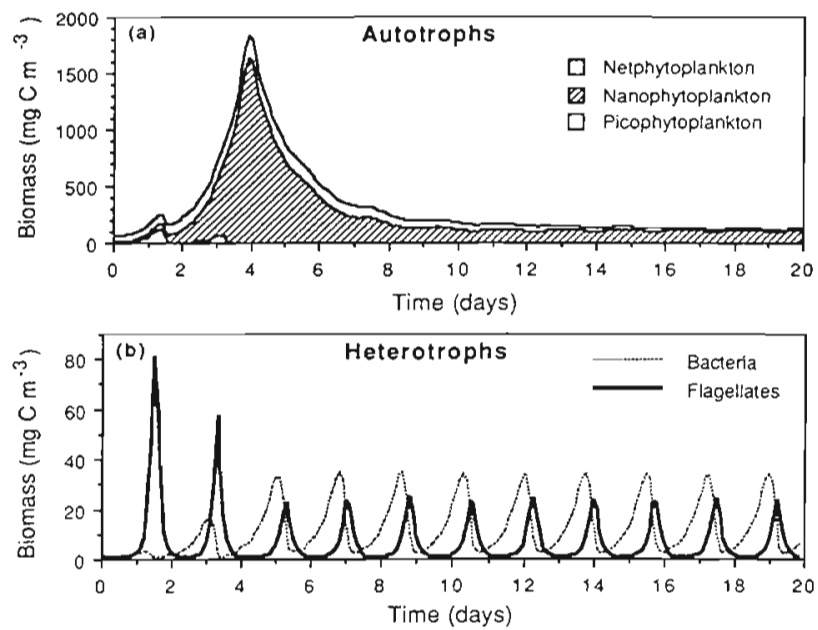

Fig. 8. Model results obtained for microcosm simulation with phytoplankton senescence increased 5 -fold after Day 4, i.e. from 10 to $50 \%$ of gross production

plankton cells, or scavenging substrates derived from heterotroph feeding processes (see Jumars et al. 1989).

In the second manipulation (Fig. 11) the initial biomass of mesozooplankton was increased from 1 to 150 $\mathrm{mg} \mathrm{C} \mathrm{m}{ }^{-3}$. The expected result was a much-reduced autotroph biomass. Instead, the magnitude of the initial nanophytoplankton bloom on Day 4 (Fig. 2a, Fig. 11a) was increased, due to limitation of microzooplankton biomass by mesozooplankton predation. Netphytoplankton were absent. The secondary nanophytoplankton bloom occurred earlier (Day 14), and
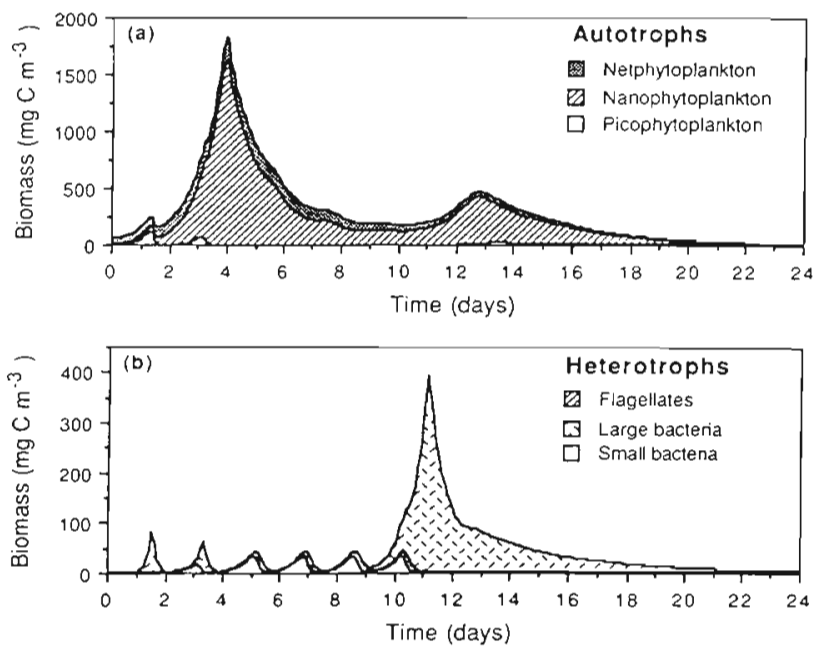

Fig. 9. Output of the microcosm simulation assuming a 5-fold increase in phytoplankton senescence after Day 4 and introducing a second, large-celled ( $1 \mu \mathrm{m}$ ESD) bacterial size-class at Day 9

was much larger than in the original model. Heterotrophs (Fig. 11b) showed 2 pulses of peak microzooplankton biomass (Days 6 \& 15) followed a day later by peaks in bacterial biomass. From these results it was evident that a large seeding stock of mesozooplankton had marked effects on the trophic structure of the planktonic food web through increased predatory control of heterotrophs (see also Riemann 1985) rather than increased grazing pressure on autotrophs.

Results of the manipulated simulations are consistent with field measurements, and show that numerous options are available for biomass relationships and sizestructure of the planktonic food web. The final modification to the simulation model was extreme. Bacteria were excluded to assess whether they are in fact an important component of the planktonic food web. Simulation results are shown on Fig. 12. The initial peaks in autotrophs and heterotrophs prior to Day 6 (Fig. 2a, b) were still present, and at similar magnitudes. After Day 6 both autotrophs and heterotrophs steadily decreased to values lower than the drogue simulation. These results support the hypothesis that bacteria contribute to an increase in the overall productivity of the planktonic food web, and that mineralisation by the microbial food web is an important process by which the productivity of phytoplankton populations is increased.

\section{ECOLOGICAL SIGNIFICANCE}

The size-based model described by Moloney \& Field (1991a) appears to produce a realistic simulation of the dynamics of a plankton community in the southern 

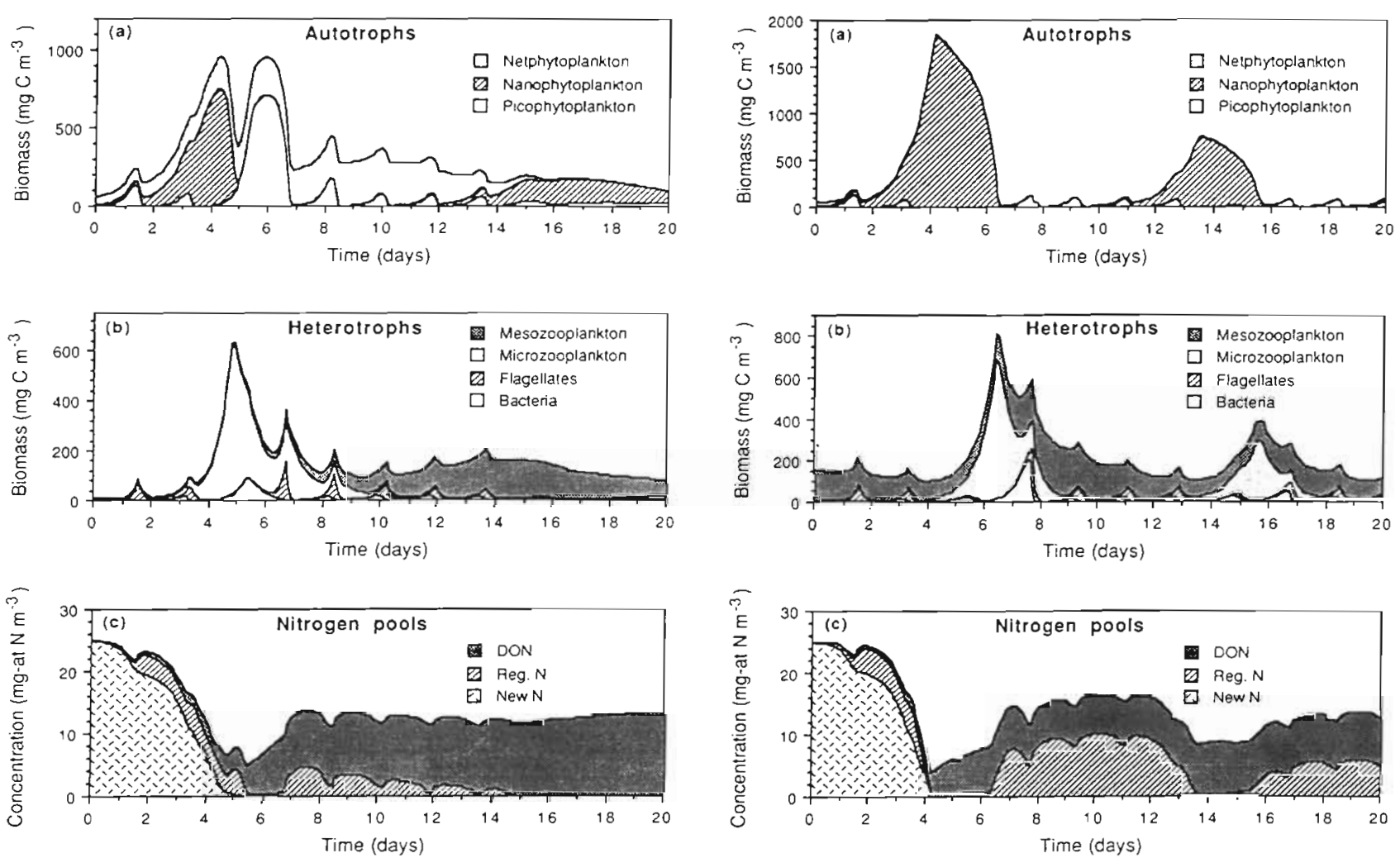

Fig. 10. Simulation output when bacteria were assumed to utilise only PDOC. Senescent phytoplankton cells were made unavailable to bacteria in the model. (a) Autotrophs. (b) Heterotrophs. (c) Nitrogen pools

Benguela upwelling region in terms of standing stocks and size composition. The model predicts rapid fluctuations in the biomass and structure of planktonic communities, which may explain the large spatial variations observed in the field.

Biomass estimates and structure of the model planktonic community show temporal variability as a result of the combined effect of substrate/food availability and predation. Competition for nitrogen sets limits to the growth of phytoplankton and bacteria, and favours small organisms which are more efficient at utilising dissolved nitrogen at low concentrations (see also Bratbak \& Thingstad 1985). Model results obtained in the simulations executed in this study demonstrate that mineralisation by the microbial food web is an important process by which the overall productivity of the planktonic community is increased, and that there is a successive dependency of 'new' and 'regenerated' nitrogen in the control of plankton dynamics.

This study clearly shows that size-dependent relationships and parameters may be used to model the planktonic community. Obviously, simulation results are dependent upon assumptions and size-classes used in the model. Manipulations performed in this study indicate that changes in seeding conditions may

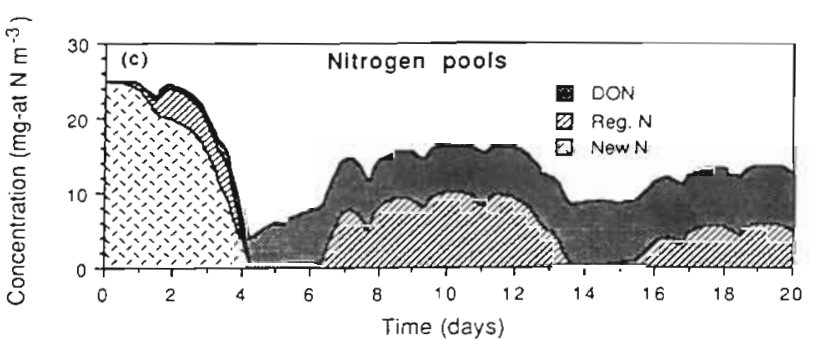

Fig. 11 Simulation output with high initial mesozooplankton biomass (150 $\mathrm{mg} \mathrm{C} \mathrm{m}^{-3}$ )
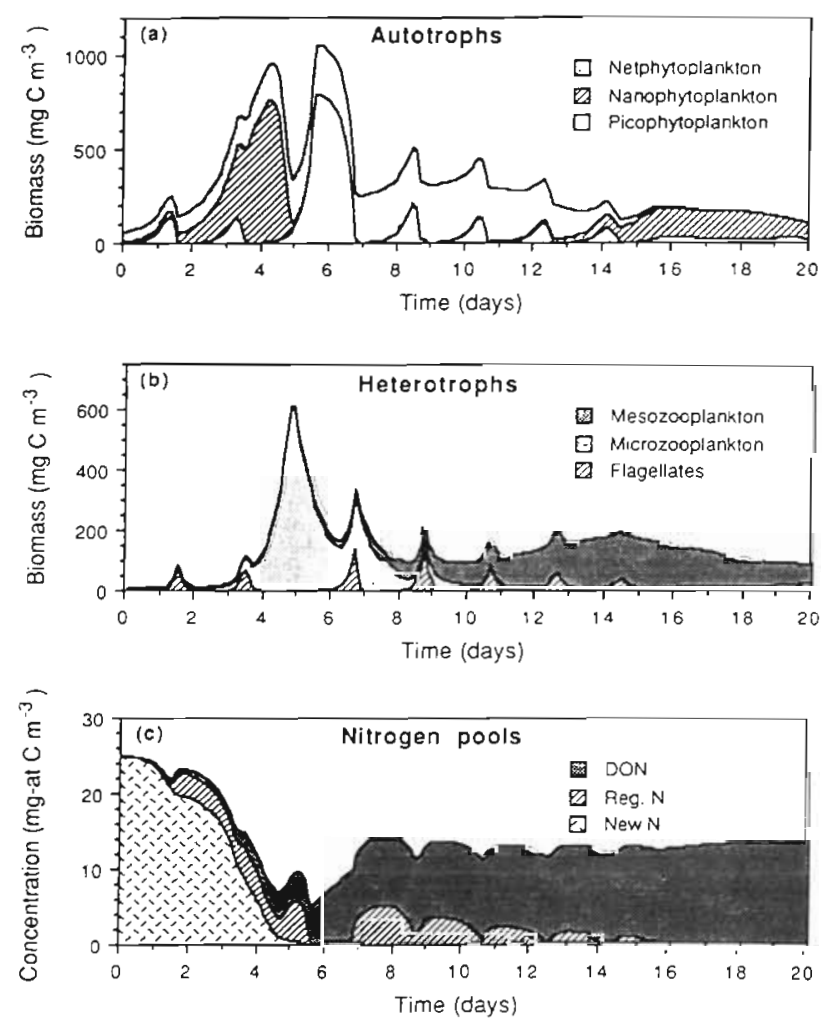

Fig. 12. Simulation output when bacteria were excluded from the model 
have marked effects on simulation output, as would be expected, and emphasises the dynamic nature of interactions within plankton communities

Some of the simplifying assumptions made in the model may not be realistic. For example, it was assumed that temperature remains constant at $13^{\circ} \mathrm{C}$, whereas the temperature in the upper mixed layer probably increases by 0.2 to $0.5^{\circ} \mathrm{C} \mathrm{d}^{-1}$ during the simulated period. Quantitative changes governed by rate processes are therefore likely to be underestimated in the simulation output. Furthermore, estimates of PDOC excretion rates are difficult to obtain, and appear to range from 10 to $80 \%$ of the total carbon fixed during photosynthesis (Wolter 1982, Lancelot 1984. Turley \& Lochte 1985, see also Jumars et al. 1989). PDOC excretion rates are influenced by a number of factors, and are likely to be higher when phytoplankton are nitrogen-limited (Lancelot 1983, see Jensen 1984). In the model PDOC production rates were assumed to be constant (15\%) at the lower end of this range. Nonetheless, bacteria were not carbon-limited and the PDOC pool was shown to accumulate carbon during the simulation, so the assumption probably does not affect model output substantially. Physical factors not included in the model are more likely to influence simulation results (e.g. decreased light attenuation, turbulence, diffusion, and deep mixing below the euphotic zone). Incorporation of these factors would increase model complexity and obscure fundamental processes involved in determining plankton dynamics. It could be argued that physical processes are the most important controlling mechanisms in plankton dynamics, particularly in pulsed upwelling regions, where alternating periods of strong winds and calmer periods are common.

In general, qualitative aspects of the model appear to produce an output consistent with laboratory and field results, making a valuable contribution towards our understanding of the dynamics of the plankton community. Observed differences in simulation results and experimental and field measurements are similarly constructive, as they provide insight into the effects of species-specific adaptations of planktonic organisms to a variable and unpredictable environment. For example, at times the allometrically-based growth rate of bacteria appears to be inconsistent with growth rates of these organisms in situ. This may be partly explained by bacterial substrate specificities and by the various strategies adopted by bacteria for surviving nutrient-poor conditions. Bacterial metabolic rates have been shown to be suppressed under starvation conditions. Adaptations in their enzyme systems enable them to survive a 'feast and famine' existence (Davis 1985, 1989, see also Painting et al. 1989). In addition, morphological plasticity enables bacteria to modulate individual cell size. Under environmental conditions in which organic substrates are deficient, natural marine bacteria are able to form dormant 'mini-cells' (Novitsky \& Morita 1978, Amy \& Morita 1983), which have lower maintenance requirements and a large surface to volume ratio which enables them to have a lower $K_{\mathrm{s}}$ value for preferred substrates. Similarly, Fenchel (1982), working on 6 species of nanoplanktonic zooflagellates, found metabolic and morphological adaptation of these organisms to starvation conditions.

Further examples of planktonic adaptations to the stochastic environment of the southern Benguela are provided by diatoms, which fall into all the size-classes in the model. These organisms may be able to sustain themselves after available nutrients are depleted, by utilising reserve supplies accumulated in the cell vacuole (Malone 1980). Furthermore, growth of diatoms may not always follow allometric rules. For example, Furnas $(1982 \mathrm{a}, \mathrm{b})$ found that diatoms had faster growth rates than microflagellates and non-motile ultraplankton in diffusion cultures. Diatoms in the southern Benguela may form resting spores under nutrient or light-limiting conditions (Pitcher 1986) and sink out of the water column rapidly, thereby avoiding bacterial degradation and forming the seed stocks for subsequent upwelling cycles. The model results have demonstrated the importance of seeding for the structure of the plankton community that develops.

Mesozooplankton may also be adapted to variable temperature and food regimes. For example, one of the species often dominant in the southern Benguela, Centropages brachiatus, has a low $Q_{10}$, so that metabolic rates are not affected by large variations in temperature (Carter 1983). Another dominant species, Calanoides carinatus, has been shown to increase tolerance to starvation in the older copepodite stages by utilising large stored lipid reserves (Borchers \& Hutchings 1986, Kosobokova et al. 1988). Lipid metabolism has similarly been suggested to maintain adults of Calanus australis during periods of starvation (Attwood \& Peterson 1989). Behavioural adaptations of mesozooplankton may also influence the dynamics of the planktonic community. It has been hypothesised that species from upwelling environments may be able to enter diapause in a late copepodite stage (C5), and remain in the aphotic zone until they are advected into surface waters during the upwelling process. During sun-warming and subsequent phytoplankton growth the diapause is reversed, and the zooplankton become metabolically active (see Borchers \& Hutchings 1986, Verheye et al. 1991). Thus large seeding stocks of mesozooplankton may be found in recently upwelled water. In the southern Benguela region, planktivorous fish such as anchovies, pilchards, round herring, 
mackerel, lanternfish and lightfish potentially exert considerable predation pressure on meso- and macrozooplankton, thereby having the effect of returning the model to its 'original' input of low mesozooplankton biomass (Hutchings et al. 1991).

\section{Assessing the importance of different processes and interactions}

The decline of phytoplankton blooms is traditionally attributed to 4 major factors: nutrient limitation, grazing, senescence and sinking (Raymont 1980). Of these factors, nutrient limitation cannot be directly responsible for declines in standing stocks, but may have an indirect effect by decreasing growth rates and enhancing senescence rates. The relative importance of grazing, senescence and sinking as pathways along which carbon fixed by plants is lost from the surface waters of the southern Benguela upwelling region is currently a topic of some debate. Phytoplankton production is high in plumes of upwelled water, but bloom duration is generally shorter than the development time of the dominant copepod species entrained in the plume. Calanoides carinatus, for example, has a development time of ca $25 \mathrm{~d}$ at temperatures of 13 to $15^{\circ} \mathrm{C}$ (Borchers \& Hutchings 1986). Unless migratory zooplankton and fish communities locate and graze the dense aggregations of phytoplankton, the bulk of the phytoplankton bloom may senesce and be lost to detritivores. As a result of the slow sinking rates of phytoplankton cells in the southern Benguela ( $<1 \mathrm{~m} \mathrm{~d}^{-1}$; Pitcher et al. 1989), a significant proportion of phytoplankton biomass and production is likely to be channelled into the microheterotroph community (see reviews by Lucas 1986 , Newell \& Turley 1987)

For simplicity, the simulation model did not include sinking of phytoplankton cells, and senescence rates were assumed to be a constant proportion (10\%) of maximum primary production rates. Despite these simplifying assumptions, it is useful to assess the relative importance of grazing, senescence and respiration in terms of carbon losses from the simulated bloom. For the duration $(20 \mathrm{~d})$ of the standard simulation (Fig. 2) it was found that respiratory carbon losses $(47 \%$ of total carbon fixed) were slightly larger than losses due to grazing $(44 \%)$. Simulated losses due to senescence were low $(10 \%$ in total), because of the assumption that senescence was $10 \%$ of maximum growth rates. However, cell senescence may approximate respiratory losses when nutrients are limiting, because rapid respiration rates exceed carbon fixation rates, causing biomasses to decline. Thus senescence or cell catabolism is an important contributor to the decline of the simulated phytoplankton bloom.
In the southern Benguela, field data indicate that the productivity of copepods is not exceptionally high (Borchers \& Hutchings 1986, Hutchings et al. 1991), possibly as a result of spatial and temporal variability in the physical environment (Borchers \& Hutchings 1986, Branch et al. 1987, Attwood \& Peterson 1989). This implies that grazing may be relatively less important than other losses in a declining phytoplankton bloom. To address this problem, we considered the simulated carbon losses for the period 10 to $20 \mathrm{~d}$, for the netphytoplankton size-class (the size-class that is grazed by copepod-sized heterotrophs in the model). Of the total carbon losses for netphytoplankton, $62 \%$ was due to grazing and $38 \%$ to respiration and senescence. The modelled mesozooplankton biomass consuming the netphytoplankton was not unrealistically large; maximum values of $280 \mathrm{mg} \mathrm{C} \mathrm{m}^{-3}$ or $5600 \mathrm{mg} \mathrm{C}$ $\mathrm{m}^{-2}$, assuming a $20 \mathrm{~m}$ deep euphotic zone (Brown \& Hutchings 1987 a), compared with maximum measured standing stocks of $4310 \mathrm{mg} \mathrm{C} \mathrm{m}^{-2}$ during Drogue 1 (see Table 6 in Painting et al. 1993).

Grazing thus appears to be an important factor contributing to the decline of the simulated netphytoplankton bloom. However, when all phytoplankton size-classes are considered, it is found that netphytoplankton production during the 10 to $20 \mathrm{~d}$ period is only $16 \%$ of total primary production, although average netphytoplankton crop is $42 \%$ of the total. Thus most of the primary production and a large proportion of the crop may be unavailable to zooplankton such as copepods, because of the small size of the dominant producers. During Days 10 to 20 in the model, mesozooplankton graze only $18 \%$ of total carbon fixed. This relatively small fraction provides sufficient energy to support a large mesozooplankton standing stock. The results from the model support the hypothesis that mesozooplankton grazing is not the main factor causing the decline of phytoplankton blooms after upwelling, because most of the phytoplankton are too small to be eaten by copepods. However, the results also show that even a small proportion of primary production is able to support a relatively large mesozooplankton standing stock (Painting et al. 1993), indicating that copepod production may be large in upwelled water at certain times.

To assess the trophic role of heterotrophic microorganisms $(<200 \mu \mathrm{m})$ in the simulation, integrated carbon and nitrogen flow networks for 3 periods $10-10$, $10-20$ and $15-20$ d) were used as inputs to network analysis (Wulff et al. 1989). Total dependency coefficients were determined, and represent the fraction of each size-class's consumption which passes through any of the other model size-classes (Kay et al. 1989), thus depicting the extended diet of any size-class. Dependency coefficients for model mesozooplankton 
Table 2. Total dependency coefficients for model mesozooplankton for 3 periods. Coefficients represent the percentage of total carbon $(\mathrm{C})$ and nitrogen $(\mathrm{N})$ consumption by mesozooplankton that passes through each model size-class. Note that totals are greater than unity because an element may pass through a number of size-classes before reaching mesozooplankton. Bold figures represent direct consumption by mesozooplankton

\begin{tabular}{|lrrrrrrr|}
\hline \multirow{2}{*}{ Size class } & \multicolumn{2}{c}{$0-10 \mathrm{~d}$} & \multicolumn{2}{c}{$10-20 \mathrm{~d}$} & \multicolumn{2}{c|}{$15-20 \mathrm{~d}$} \\
& $\mathrm{C}$ & $\mathrm{N}$ & $\mathrm{C}$ & $\mathrm{N}$ & $\mathrm{C}$ & $\mathrm{N}$ \\
\hline Picophytoplankton & 6 & 46 & & 0.5 & 26 & 0.2 & 8 \\
Nanophytoplankton & 18 & 61 & 7.9 & 25 & 21 & 22 \\
Netphytoplankton & 76 & $\mathbf{7 0}$ & $\mathbf{9 1 . 6}$ & $\mathbf{9 5}$ & 22 & 21 \\
Bacteria & 0.6 & 32 & 0.2 & 24 & 0.2 & 13 \\
Flagellates & 6 & 46 & 0.7 & 31 & 0.4 & 12 \\
Microzooplankton & $\mathbf{2 4}$ & $\mathbf{6 9}$ & $\mathbf{8 . 5}$ & $\mathbf{2 0}$ & $\mathbf{2 1}$ & $\mathbf{2 2}$ \\
& & & & & & \\
\hline
\end{tabular}

during different periods of the model output are presented in Table 2.

The mesozooplankton size-class is 'top predator' in our model. Consequently, some fraction of the carbon and nitrogen consumed by mesozooplankton passes through every other size-class in the model. During the first $10 \mathrm{~d}$ of the simulation, mesozooplankton depend mainly on netphytoplankton for carbon, but depend equally on netphytoplankton and microzooplankton for nitrogen (Table 2). This may be explained by different $\mathrm{C}: \mathrm{N}$ ratios of prey; netphytoplankton have a $\mathrm{C}: \mathrm{N}$ of 6 , and microzooplankton have a $C: N$ of 4 (Moloney \& Field 1991a, Table 1). At the height of the simulated netphytoplankton bloom (Days 10 to 20) mesozooplankton depend almost entirely on netphytoplankton for both carbon and nitrogen (Table 2). This is not surprising, because average netphytoplankton standing stocks during this period are large, whereas microzooplankton standing stocks are very much reduced after Day 10 (Fig. 2). Mesozooplankton are largely herbivorous and food chains are short. During the last $5 \mathrm{~d}$ of the bloom, biomasses of both major prey items of mesozooplankton are reduced (Fig. 2), and dependencies are equal (Table 2). With regard to the other size-classes in the model, the mesozooplankton have large nitrogen dependency coefficients on other components of the microbial food web. They are largely carnivorous and food chains are long. These results indicate that interactions between autotrophic and heterotrophic components are important in enhancing nitrogen flows in the model system. Because nitrogen is probably the limiting nutrient for primary production in the southern Benguela upwelling system (Andrews \& Hutchings 1980), the microbial food web plays an important role in nitrogen cycling, and in the production of zooplankton (Table 2). This is particularly true after depletion of nitrate in maturing upwelled water, when microheterotrophic pathways dominate the pelagic food web. The frequency of upwelling may thus be an important fac- tor determining the relative dominance of short diatom-copepod food chains or microbial food webs, and therefore the annual yield of pelagic fish.

Acknowledgements. We are indebted to many people who participated in the field and laboratory studies discussed here, particularly Dave Muir, Geoff Bailey, Penny Brown, Betty Mitchell-Innes, Bill Peterson and Frieda Verheye-Dua. We thank Larry Hutchings, Trevor Probyn, Hans Verheye and John Field for constructive comments on earlier drafts of this manuscript. Financial support for C.L.M. and M.I.L. was provided by the Benguela Ecology Programme (BEP), funded by the Foundation for Research Development (FRD). The financial and logistic support of the Sea Fisheries Research Institute is gratefully acknowledged

\section{LITERATURE CITED}

Amy, P. S., Morita, R. Y. (1983). Protein patterns of growing and starved cells of a marine Vibrio sp. Appl. environ. Microbiol. 45: 1748-1752

Andrews, W. R. H., Hutchings, L. (1980). Upwelling in the southern Benguela Current. Prog. Oceanogr. 9: 1-81

Attwood, C. G., Peterson, W. T (1989). Reduction in fecundity and lipids of the copepod Calanus australis (Brodskii) by strongly pulsed upwelling. J. exp. mar. Biol. Ecol. 129: $121-131$

Azam, F., Fenchel, T., Field, J. G., Gray, J. S., Meyer-Reil, L. A., Thingstad, F. (1983). The ecological role of water column microbes in the sea. Mar Ecol. Prog. Ser. 10: 257-263

Barlow, R. G. (1982). Phytoplankton ecology in the southern Benguela Current. 3. Dynamics of a bloom. J exp. mar. Biol. Ecol. 63: 239-248

Bloem, J., Bär-Gilissen, M. J B., Cappenberg, T E. (1986). Fixation, counting and manipulation of heterotrophic nanoflagellates. Appl. environ. Microbiol. 52: 1266-1272

Borchers, P., Hutchings, L. (1986). Starvation tolerance, development time and egg production of Calanoides carinatus in the southern Benguela Current. J. Plankton Res. 8: $855-874$

Branch, G. M., Barkai, A., Hockey, P. A. R., Hutchings, L. (1987). Biological interactions: causes or effects of variability in the Benguela ecosystem? In: Payne, A. I. L., Gulland, J. A., Brink, K. H. (eds.) The Benguela and comparable ecosystems. S. Afr. J. mar. Sci. 5: 425-445

Bratbak, G., Thingstad, T F. (1985). Phytoplankton-bacteria interactions: an apparent paradox? Analysis of a model system with both competition and commensalism. Mar. Ecol. Prog. Ser. 25: 23-30

Brown, P. C., Hutchings, L. (1987a). The development and decline of phytoplankton blooms in the southern Benguela upwelling system. 1 Drogue movements, hydrography and bloom development. In: Payne, A. I. L., Gulland, J. A., Brink, K. H. (eds.) The Benguela and comparable ecosystems. S. Afr. J. mar. Sci. 5: 357-391

Brown, P. C., Hutchings, L. (1987b). The development and decline of phytoplankton blooms in the southern Benguela upwelling system. 2. Nutrient relationships. In: Payne, 
A. I. L., Gulland, J. A., Brink, K. H. (eds.) The Benguela and comparable ecosystems. S. Afr. J. mar. Sci. 5: 393-409

Brown, P. C., Painting, S. J., Cochrane, K. L (1992). Estimates of phytoplankton and bacterial biomass and production in the northern and southern Benguela ecosystems. S. Afr. J mar. Sci. 11: $537-564$

Carter, R. A. (1983). The role of plankton and micronekton in carbon flow through a southern Benguela kelp bed. Ph.D. thesis, University of Cape Town

Cousins, S. H. (1985). The trophic continuum in marine ecosystems: structure and equations for a predictive model In: Ulanowicz, R. E., Platt, T (eds.) Ecosystem theory for biological oceanography. Can. Bull. Fish. Aquat. Sci. 213: $76-93$

Davis, C. L. (1985). Physiological and ecological studies of mannitol utilising marine bacteria. Ph.D. thesis, University of Cape Town

Davis, C. L. (1989). Uptake and incorporation of thymidine by bacterial isolates from an upwelling environment. Appl. environ. Microbiol. 55: 1267-1272

Fenchel, T (1982). Ecology of heterotrophic microflagellates III. Adaptations to heterogeneous environments. Mar Ecol. Prog. Ser. 9: 25-33

Furnas, M. J. (1982a). An evaluation of two diffusion culture techniques for estimating phytoplankton growth rates in situ. Mar. Biol. 70: 63-72

Furnas, M. J. (1982b). Growth rates of summer nanoplankton $(<1.0 \mu \mathrm{m})$ populations in lower Narragansett Bay, Rhode Island, USA. Mar. Biol. 70: 105-115

Hutchings, L. (1992). Fish harvesting in a variable, productive environment - searching for rules or searching for exceptions? In: Payne, A. I. L., Brink, K. H., Mann, K. H., Hilborn, R. (eds.) Benguela trophic functioning. S. A.fr. J mar. Sci. 12: 297-318

Hutchings, L., Pillar, S. C., Verheye, H. M. S. (1991). Estimates of standing stock, production and consumption of mesoand macrozooplankton in the Benguel.a Ecosystem. S. Afr. J. mar. Sci 11: 499-512

James, A. G. (1987). Feeding ecology, diet and field-based studies on feeding selectivity of the Cape anchovy Engraulis capensis Gilchrist. In: Payne, A. I. L., Gulland, J. A., Brink, K. H. (eds.) The Benguela and comparable ecosystems. S. Afr. J. mar. Sci. 5: 673-692

Jensen, A. (1984). Excretion of organic carbon as a function of nutrient stress. In: Holm-Hansen, O., Bolis, L., Gillies, R. (eds.) Marine phytoplankton and productivity. Lecture notes on coastal and estuarine studies 8 . Springer-Verlag, Berlın, p. 61-72

Jumars, P. A., Punry, D. L., Baross, J. A., Perry, M. J., Frost, 33. W. (1989). (:losing the microbial loop: dissolved carbon pathways to heterotrophic bacteria from incomplete ingestion, digestion and absnrption in animals. Deep Sea Res. 36: 483-495

Kay, J. J., Graham, L. A., Ulanowicz, R. E. (1989). A detraled guide to network analysis. In: Wulff, F., Field, J. G., Mann, K. H. (eds.) Network analysis in marine ecology: methods and applications. Springer-Verlag, Berlin, p. 15-61

Kosobokova, K. N., Drits, A. V., Krylon, P I. (1988). Physiological and biochemical characteristics of Calanoides carinatus in waters of an upwelling of the coast of Namibia. Oceanology 28: 375-379

Lancelot, C. (1983). Factors affecting phytoplankton extracellular release in the southern bight of the North Sea. Mar. Ecol. Prog. Ser. 12: 115-121

Lancelot, C. (1984). Extracellular release of small and large molecules by phytoplankton in the southern bight of the North Sea. Estuar. coast. Shelf Sci. 18: 65-77
Lucas, M. 1. (1986). Decomposition in pelagic marine ecosystems. J. Limnol. Soc. S. Afr. 12: 99-122

Lucas, M. I., Probyn, T A., Painting, S. J (1987). An experimental study of microflagellate bacterivory: further evidence for the importance and complexity of microplanktonic interactions. In: Payne, A. I. L., Gulland, J. A., Brink, K. H. (eds.) The Benguela and comparable ecosystems. S. Afr. J. mar. Sci. 5: 791-808

Malone, T. C. (1980). Algal size. In: Morris, I. (ed.) The physiological ecology of phytoplankton. Blackwell Scientific Publications, London, p. 433-463

Matthews, S. G. (1991). The relative role of protozoans in the flux of phytoplankton nitrogen through pelagic food webs. M.Sc. thesis, University of Cape Town

Moloney, C. L., Field, J. G. (1989). General allometric equations for rates of nutrient uptake, ingestion and respiration in planktonic organisms. Limnol. Oceanogr. 34 : $1290-1299$

Moloney, C. L., Field, J. G. (1991a). The size-based dynamics of plankton food webs. I. A simulation model of carbon. and nitrogen. flows. J. Plankton Res. 13: 1003-1038

Moloney, C. L., Field, J. G. (1991b). Modelling carbon and nitrogen flows in a microbial plankton community. In: Rejd. P. C., Burkhill, P. H., Turley, C. M. (eds.) Protozoa and their role in marine processes. NATO ASI series. SpringerVerlag, New York, p. 443-474

Moloney, C. L., Field, J. G., Lucas, M. I. (1991). The size-based dynamics of plankton food webs. II. Simulations of three contrasting southern Benguela food webs. J. Plankton Res. 13: $1039-1092$

Newell, R. C., Linley, E. A. S. (1984). Significance of microheterotrophs in the decomposition of phytoplankton: estimates of carbon and nitrogen flow based on the biomass of plankton communities. Mar. Ecol. Prog. Ser. 16: 105-119

Newell, R. C., Turley, C. M. (1987). Carbon and nitrogen flow through pelagic microheterotrophic communities. In: Payne, A. I. L., Gulland, J. A., Brink, K. H. (eds.) The Benguela and comparable ecosystems. S. Afr. J. mar. Sci. 5: $717-734$

Novitsky, J. A., Morita, R. Y. (1978). Possible strategy for the survival of marine bacteria under starvation conditions. Mar. Biol. 48: 289-295

Painting, S. J., Lucas, M. I., Muir, D. G. (1989). Fluctuations in helerotrophic bacterial community structure, activity and production in response to development and decay of phytoplankton in a microcosm. Mar. Ecol. Prog. Ser. 53: 129-141

Painting, S. J., Moloney, C. L., Probyn, T A., Tibbles, B. (1992). Microheterotrophic pathways in the southern Benguela upwelling system. In: Payne, A. I. L., Brink. K. H., Mann, K. H., Hilborn, R. (eds.) Benguela trophic functioning. S. Afr. J. mar. Sci. 12: 527-543

Painting, S. J., Lucas, M. I., Peterson, W. T., Brown, P. C., Hutchings, L., Mitchell-Innes, B. A. (1993). Dynamics of bacterioplankton, phytoplankton and mesozooplankton communities during the development of an upwelling plume in the southern Benquela. Mar Ecol. Prog. Ser 100: $35-53$

Parsons, T R., Takahashı, M., Hargrave, B. (1984). Biological oceanographic processes, 3rd edn. Pergamon, Oxford

Peterson, W. T., Painting, S. J., Hutchings, L. (1990). Diel variatıons in gut pigment content, diel vertical migration and estimates of grazing impact for copepods in the southern Benguela upwelling region in October $1987 \mathrm{~J}$ Plankton Res. 12: 259-281

Pitcher, G. C. (1986). Sedimentary flux and the formation of 
resting spores of selected Chaetoceros species at two sites in the southern Benguela system. S. Afr. J. mar. Sci. 4: $231-244$

Pitcher, G. C., Walker, D. R., Mitchell-Innes, B. A. (1989). Phytoplankton sinking rate dynamics in the southern Benguela upwelling system. Mar. Ecol. Prog. Ser. 55: 261-269

Probyn, T A. (1985). Nitrogen uptake by size-fractionated phytoplankton populations in the southern Benguela upwelling system. Mar. Ecol. Prog. Ser. 22: 249-258

Probyn, T A. (1987). Ammonium regeneration by microplankton in an upwelling environment. Mar Ecol. Prog. Ser. 37: 53-64

Probyn, T. A. (1992). The inorganic nitrogen nutrition of phytoplankton in the southern Benguela: new production, phytoplankton size and implications for pelagic food webs. In: Payne, A. I. L., Brink, K. H., Mann, K. H., Hilborn, R. (eds.) Benguela trophic functioning. S. Afr. J. mar. Sci. 12: 411-420

Raymont, J E. G. (1980). Plankton and productivity in the oceans, 2nd edn, Vol. 1. Phytoplankton. Pergamon, Oxford

Riemann, B. (1985). Potential importance of fish predation and zooplankton grazing on natural populations of freshwater bacteria. Appl. environ. Microbiol. 50: $187-193$

Ryther, J. H. (1969). Photosynthesis and fish production in the sea. Science 166: 72-76

Sieburth, J McN. (1984). Protozoan bacterivory in pelagic marine waters. In: Hobbie, J. E., Williams, P. le B. (eds.) Heterotrophic activity in the sea. NATO Conference series IV: Marine sciences. Plenum Press, New York, p. $405-444$

Stockner, J. G, Antia, N. J. (1986). Algal picoplankton

This article was presented by J. G. Field, Rondebosch, South Africa from marine and freshwater ecosystems; a multidisciplinary perspective. Can. J. Fish. Aquat. Sci. 43: 2472-2503

Strathmann, R. R. (1967). Estimating the organic carbon content of phytoplankton from cell volume or plasma volume. Limnol. Oceanogr 12:411-418

Turley, C. M., Lochte, K. (1985). Direct measurement of bactenal productivity in stratified waters close to a front in the Irish Sea. Mar. Ecol. Prog. Ser. 23: 209-219

Ulanowicz, R. E. (1986). Growth and development: ecosystems phenomenology. Springer-Verlag, New York

verheye, H. M. (1991). Short-term vanability during an anchor station study in the southern Benguela upwelling system: abundance, distribution and estimated production of mesozooplankton with special reference to Calanoides carinatus Kroyer. Prog. Oceanogr. 28: 91-119

Verheye, H. M., Hutchings, L., Peterson, W. T. (1991). Life history and population maintenance strategies of Calanoides carinatus (Copepoda: Calanoida) in the southern Benguela region. S. Afr. J. mar. Sci. 11: 179-191

Verheye, H. M., Hutchings, L., Huggett, J. A., Painting, S. J. (1992). Mesozooplankton dynamics in the Benguela ecosystem with emphasis on the herbivorous copepods. In Payne, A. I. L., Brink, K. H., Mann, K. H., Hilborn, R. (eds.) Benguela trophic functioning. S. Afr J. mar. Sci. 12 : $561-584$

Williams, P. J. le B. (1981). Incorporation of microheterotrophic processes into the classical paradigm of the planktonic food web. Kieler Meeresforsch., Sondh. 5: 1-28

Wolter, K. (1982). Bacterial incorporation of organic substances released by natural phytoplankton populations Mar. Ecol. Prog. Ser. 7: 287-295

Wulff, F., Field, J G., Mann, K. H. (eds.) (1989). Network analysis in marine ecology: methods and applications Springer-Verlag, Berlin

Manuscript first received: August 30, 1991

Revised version accepted: April 26, 1993 